\title{
THE EFFECTIVENESS OF JAKARTA SMART CITY APPLICATION IN ENHANCING COMMUNITY RESILIENCE IN FACING FLOOD RISK
}

\author{
Linda Widiachristy ${ }^{*}$, Adinda Smaradhana Rachmanto ${ }^{* *}$ \\ * Department of Urban Environmental Management, Wageningen University and \\ Research, Netherland \\ ${ }^{* *}$ School of Architecture and Built Environment, KTH Royal Institute of \\ Technology, Sweden \\ e-mail: lindawdty@gmail.com
}

\begin{abstract}
Jakarta is the most populated city in Indonesia with a long history of natural disasters, particularly floods. The city's geographical condition has been the leading cause of the recurrent floods that have happened over the years. This situation has predominantly affected the people living in the flood-prone locations in several settlements along the Ciliwung riverbanks. The government has conducted various efforts to enhance the city resilience towards flood incidence, including utilizing smart city approach, such as flood monitoring applications to give real-time information related to specific circumstances that possibly caused flooding. This effort aims to increase community awareness toward disaster events. This paper seeks to analyze the effectiveness of people using the flood mitigation application as an early warning system in Jakarta. To construct this objective, questions such as to what extent people are familiar with the application, how much they understand its function, and whether they face any difficulties in using the application during the flood events are proposed. The quantitative approach is being used to gather people's opinions towards the application, specifically JAKI. Preliminary results suggest that there are still some gaps in the implementation of technology applied with how society comprehends it, resulting in the interference with the application's intention as an early warning system. Some essential features that need to be reformed favouring public use are the application basis, target group, data selection, and application in disaster management schemes. While the research is still ongoing, an understanding that technology should be aligned with the community's ability to use it should be redefined to implement intelligent city principles in Jakarta.
\end{abstract}

Keywords: smart city, community resilience, flood, early warning system 


\section{INTRODUCTION}

\section{Smart City Concept}

Nowadays, many people decided to live in an urban area. The United Nations (2018) expected that $68 \%$ of the human population would reside in the city by 2050 . Questions such as how could the city maintain the inhabitants' quality of life while some threats, such as natural disasters, environmental issues, and segregation, are mainly discussed in many places (Zhu, Li \& Feng, 2019). Conventional solutions are no longer capable of solving present situations. Thus more compelling and conceivable solutions are needed. The rapid development of technology is considered as a potential to develop creative, efficient, and practical solutions in a situation that changes swiftly (Bansal et al., 2017). The concept of a smart city then emerges by an understanding that cities could tackle a complex urban problem using various new technologies such as the Internet of Things (IoT), machine learning, and big data (Han \& Hawken, 2018). It is also argued that intelligent cities could play a more significant role in improving city resilience, especially in facing crises and disasters (Marana et al., 2019).

According to Godschalk (2003), the concept of a resilient city is a city that could cope with any pressure without creating chaos that can lead to permanent damage to the city. Moreover, it also describes a capacity that could return the city's condition before a disaster. The concept of resilience city itself shares a similar pattern with the sustainable city, which comprises mitigation, adaptation, and innovation (Mandala, 2013). Based on Renald (2016), there are four critical factors in designing disaster-prone cities in Indonesia, which are (1) spatial management, (2) disaster adaptation, (3) disaster mitigation, and (4) technological innovation.

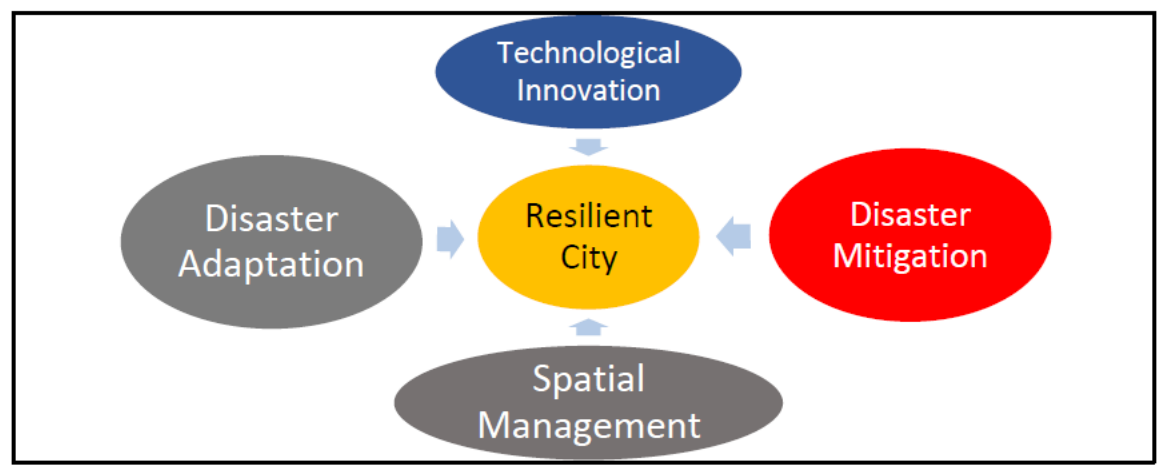

Figure 1. The framework of Resilience of Disaster Prone Cities (Renald et al., 2016)

Nowadays, some cities worldwide have started to implement the concept of a smart city in their disaster management projects. The use of intelligent city platforms such as IoT and social media have been acknowledged by the government and related agencies as a valuable source of information and work as communication 
channels in disaster response and management because of the ability to give quick answers to the public (Kreiner \& Neubauer, 2012).

As the capital of Indonesia, Jakarta could be seen as a city that is vulnerable to various disasters; both considered a natural disaster or the one that is affected by human activities (World Bank, 2016). The capital itself has a long history of disaster, which flood is considered the most frequent one (Sitinjak et al., 2018). It is argued that the leading cause of the flooding is related to the city's geographical condition that is $40 \%$ located below the sea level and being crossed by thirteen natural rivers such as the Ciliwung river, Angke River, and Grogol river (Jakarta Smart City, 2016). The recurrent floods have affected the people, predominantly the poor, who live in the flood-prone locations, specifically along the Ciliwung riverbanks, located in the central of Jakarta.

In Jakarta, many inhabitants live in the riverbank area that is considered a vulnerable area to flood activities. According to the World Bank (2015), living alongside the riverbank area is the only option for some people due to the high cost to afford a settlement in Jakarta. In other words, the people acknowledged the risk of flood, yet they still live near the riverbank area. The Jakarta government also made some efforts to minimize the impact by implementing various programs related to this issue. It started from normalizing the river condition, which adapts the current physical state to accommodate the water flow, installing an Automatic Water Level Recorder (AWLR) to get a continuous report of the river water level (Jakarta Smart City, 2014; Jakarta Smart City, 2013). The latest effort was considered as a mitigation strategy. The project aims to give an Early Warning System (EWS) to the inhabitants if the condition of the river indicates possible flooding. EWS has been acknowledged as a valuable tool to save lives, prevent damage, and increase society's capability (Cools et al., 2016). The purpose and concept of the flood risk management system adopted by Jakarta city will be explained in the next subchapter.

\section{Flood Risk Management in Jakarta}

In the early stage of mitigating the impact of flooding in the city, The Provincial Disaster Management Agency (BPBD) DKI Jakarta actively deployed personnel in all its wards during the rainy season. The personnel expected to respond quickly to flood-related risks, such as unclogging street drains (World Bank, 2016). The government then processed reports to execute necessary actions to avoid threats that impacted the inhabitants. Moreover, since September 2016, the government started to install several devices providing real-time information regarding the water level condition in selected rivers. They utilize an Automatic Water Level Recorder (AWLR) device to report a water level from each flood gate every two minutes and inform it to the government website (Jakarta Smart City, 2017). AWLR and around 5.600 CCTVs were also installed in various river gates and monitored continuously by the Jakarta Smart City portal. As part of the government of Jakarta, Jakarta Smart City (JSC), established in 2014, focuses on the implementation of ICT in public services. One of their services is related to disaster events, especially floods. Some of their features in their application includes data of daily rain prediction, flood gate 
monitoring, 3D visualization from an area affected by the flood, flood history, and refugee data (GNFI, 2020). The local stakeholders could access data to enhance their capacity in anticipating a plausible disaster in the future.

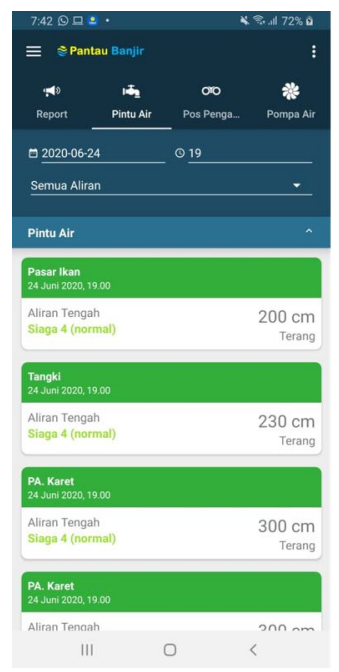

A

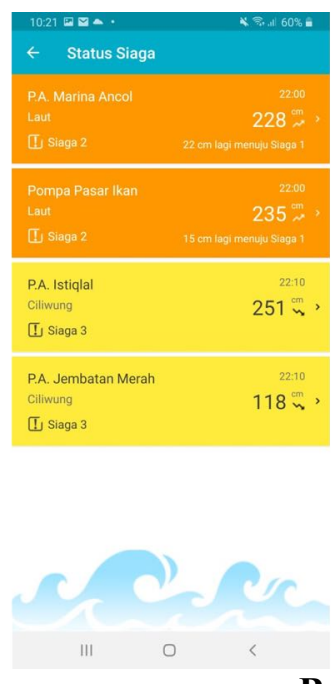

B

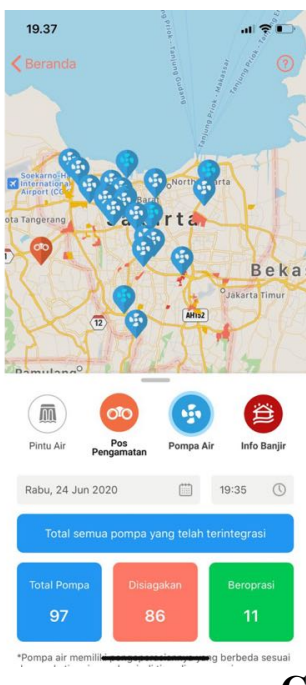

C

Figure 2. (a) Menu report of Flood Monitoring App (Pantau Banjir); (b) Status in the flood monitoring app (Sistem Deteksi Dini Banjir); (c) Status of water pump and area affected by flood (JAKI)

Furthermore, the community can also access the information from their mobile phone while also participating in monitoring the flood activity in their neighbourhood. They could access the report or complaint sections in the applications and mention the related stakeholders using social media, e.g. Twitter. Having access to the information, the community is expected to actively participate in the mitigation actions and increase their flood-risk awareness.

However, the effectiveness of using those applications to mitigate the flood potential in Jakarta is relatively new, especially at the community level, considering only 50.000-100.000 users install it both in android and iOS systems. This number is deemed low compared to the number of inhabitants in Jakarta that reach 10,5 million (BPS, 2019). Even though Indonesia is one of the countries with a high percentage of people accessing the internet, some access it for entertainment purposes (APJII, 2019). This paper focuses on examining the effectiveness of an EWS system implemented through a mobile application to mitigate the impact of flooding in one of the settlements that are frequently affected by flood in Jakarta. 


\section{THEORY / RESEARCH METHODS}

This paper aims to answer two research questions which are:

1. How much do the inhabitants that live in Jakarta use the government's flood risk applications?

2. How does the application help them to mitigate the flooding?

\section{Data collection: Survey and Interview}

In terms of answering the research questions, this research used a quantitative method. The questionnaire was selected as a tool for data collection due to its ability to gather opinions without a purpose to observe each person's views in the selected population (Jansen, 2010). Using this method is to measure the level of understanding of how the application works and how it helps them mitigate the flood. The questionnaire was distributed through an online platform named Netigate to residents living in Jakarta. The resulting objective in this study is to see how much they are familiar with the application, how much they understand the application's function and the challenge that the community faces being involved in the ICT innovation projects in maintaining disaster activity in their area. Besides the questionnaire, an in-depth interview with a respondent was also held to gather more information regarding the user experience when using the application and gain some insights into the current flood mitigation system.

\section{Delimitation of the study}

Jakarta Kini (JAKI) was selected as the application that will be analyzed because it is more popular and available in android and iOS platforms than other flood monitoring applications such as Pantau Banjir, Sistem Deteksi Dini Banjir. JAKI was launched by the Jakarta Smart City technical unit in 2019 and worked as an integrated platform for public service channels that connect the people and the regional working unit (SKPD) in Jakarta. One of JAKI's main features is JakWarta, JakRespons, JakPangan, JakPantau, JakCLM, JakSiaga, and JakAman.

In this research, the focus was the 'JakPantau' which is a feature that cooperates with flood predicting companies and BPBD to respond to flood issues that happen in Jakarta. There are four real-time information in this feature concerning the watergate status, the flood surveillance post, operating status of the water pump, and the water level updates in each sub-district. All of this information is integrated into the GIS map of Jakarta and can be adjusted accurately to specific dates and times.

\section{RESULTS AND DISCUSSION}

Based on the analysis of the data gathered from the questionnaire and interview, many inhabitants are still unfamiliar with the 'JakPantau' component as a flood monitoring feature in JAKI's application. The percentage of people who downloaded 
the application is considerably low, around $0,01 \%$, compared to Jakarta's total inhabitants. $74 \%$ of the respondents answered that they were unaware of the existence and the use of this application in mitigating the flood.

Another statement also made from the interview with the respondent. He mentioned that he never uses JAKI for an activity related to flooding and only uses this application for reporting infrastructural damage in his neighbourhood. One of the reasons is because the flood risk section in this application only shows spatial information that is hard to digest for the people who do not have shared knowledge regarding the flood.

Furthermore, almost all the respondents also mentioned that they prefer to get information from social media and news on television rather than the application. Though, once they learned about the function of this application and how to use it, most of them agreed that the application is quite informative and helpful.

Based on the theoretical review and several assumptions, some aspects of the JAKI application need improvements to increase its effectiveness and strengthen its role as an early warning system. To enhance JAKI's potential in future flood disaster management, several aspects need to be considered as follows:

1. Application Basis

Based on the survey and interview result, most people are still dependent on the media to get real-time information about flooding. On the other hand, UNISDR, as quoted by Cools et al. (2016), emphasized that an effective early warning system needs to cover various components, starting with the thorough community response. An early warning system commonly consists of risk knowledge, monitoring, forecasting, warning, communication of an early warning, and response capability (Cools et al., 2016). Lack of consideration towards these aspects could make the application work ineffectively to act as an early warning system in reducing impacts while disaster occurred.

2. Target Group

Identifying the target group of the apps is crucial to shaping a proper approach for the user's interface. As a flood mitigation app, Jakarta still works only as a tool for the government to share one-way information regarding the infrastructure status. The community still lacks the knowledge on how to use this application, for instance, providing information with a crowdsourcing approach. Furthermore, the application also needs to consider its local institutional capacity while processing the data. Anders et al. (2018) mentioned that technology should understand the ability of its user to adapt and engage in it and achieve the target of provided technology.

3. Data Selection

The data provided in JakPantau, which contains information, such as water pump and watergate status, is a compilation of data used by BPBD and other departments regarding floods. When a flood happens, BPBD will determine the flooding point; the Social Department will submit the number of victims, whereas the Department of Natural Resources will gather the water level data in each sluice (JSC, 2020). Thus, the information shown is very technical and quite challenging for the community to comprehend. 


\section{Flood Mitigation Schemes}

For comparison, Japan Meteorological Agency has developed J-Alert as a disaster information sharing system to distribute warning alerts to the residents by broadcasting through mobile phones, radios, television news, and SNS. The system is divided into five levels with clear evacuation instructions symbolized in ordinal numbers (NHK, 2019). While JakPantau only provides the physical data about the floods and lacks in giving the community's evacuation instructions. Moreover, the notification in JAKI can only be used by the registered users, and only at a certain level of the flood risk will the government blast the SMS as a warning notice to the people.

\section{CONCLUSIONS}

Technological innovation has brought a significant change to the current disaster management, particularly the prevention and mitigation measures. The classic technical approach, such as investing in complex infrastructure to anticipate the flood risk, needs to be supported with the effort between the government and community in sharing the accurate data and practical information required for emergencies.

The application plays a role as the bridge between the government and community to gather real-time information, planning responses and evaluate the mitigation plan in flood management. If this system is optimized, how the community knows how to use the information in real situations will help the community be more prepared when the floods happen. Many people who live in Jakarta are still unfamiliar with using the application since there are no clear instructions on using it correctly from the government, which led them to rely on the conventional way to detect floods. The information, such as the water pump condition or the water level, is still too hard to digest for the public with no background in water management.

This proved that the position of the intelligent city system in disaster management in Jakarta is still novel both for the government and the public, where currently, it only works as a one-way information tool. To avoid data confusion, the government can simplify the data in a way that the public understands. This lead to these two main takeaways as suggestions on the JAKI application:

1. Create a more user-friendly interface with more features related to flood mitigation to be more effective to use and work as flood education tools for the community.

2. Establish a clear position for this application in flood disaster management and socialize it to the public, not only as supporting tools but also as a crucial part of taking prevention and mitigation measures.

This research has presented the preliminary findings, particularly to what kind of implications might affect the effectiveness of this application as the early warning system in JakartaWhile the investigation is still ongoing. It could be understood that technology should integrate with its user needs to achieve the effectiveness of the provided technology. Implementing a smart city is still considered as heavily 
focused on the advancement of the technology itself, thus disconnected from its user. Further examination would focus on the expectation of the affected inhabitants towards the current early warning system provided by the government. An understanding that a bottom-up approach could be essential to enhance the participation process during a mitigation action towards a disaster risk would be beneficial to the government while developing a technology-based project in the future.

\section{REFERENCES}

Bansal, N., Mukherjee, M., \& Gairola, A. (2017). From poverty, inequality to Smart City. Springer Transactions in Civil \& Environmental Engineering, 109-122.

Cools, J., Innocenti, D., \& O'Brien, S. (2016) Lessons from flood early warning systems. Environmental Science \& Policy, 58 (2016) 117-122

GNFI (2020), Dengan Portal Ini, Banjir Jakarta Bisa Dipantau, $<$ https://www.goodnewsfromindonesia.id/2020/01/22/dengan-portal-inibanjir-jakarta-bisa-dipantau $>$ (Accessed on 20 June 2020)

Godschalk, D.R. (2003). Urban Hazard Mitigation: Creating Resilient Cities. Natural Hazards Review. Vol. 4, No. 3, PP 136-143.

Han, H., \& Hawken, S. (2018). Introduction: Innovation and identity in nextgeneration intelligent cities. City Culture and Society, 12(December), 1-4.

Jakarta Smart City (2016), Bagaimana Pemprov DKI Jakarta Menormalisasi Sungai?, <https://smartcity.jakarta.go.id/blog/93/bagaimana-pemprov-dkijakarta-menormalisasi-sungai $>$ (Accessed on 20 June 2020)

Jakarta Smart City (2017), Automatic Water Level Recorder: Alat Pengukur Tinggi Muka Air untuk Penanganan Banjir di Ibukota, $<$ https://smartcity.jakarta.go.id/blog/172/automatic-water-level-recorder-alatpengukur-tinggi-muka-air-untuk-penanganan-banjir-di-ibukota $>$ (Accessed on 20 June 2020)

Jansen, H. (2010). The Logic of Qualitative Survey Research and its Position in the Field of Social Research Methods. Forum: Qualitative Social Research, 11 (2010)

Kompas (2020), Luapan Kali Ciliwung Sebabkan 13 RW di Jakarta Timur Kebanjiran hingga Ribuan Warga Mengungsi, $<$ https://megapolitan.kompas.com/read/2020/02/21/09335301/luapan-kaliciliwung-sebabkan-13-rw-di-jakarta-timur-kebanjiran-hingga?page=all $>$ (Accessed 21 June 2020)

Kreiner, K., \& Neubauer, G. (2012). Social media for crisis Management: Problems and challenges from an IT perspective. In the 20th conference of interdisciplinary information management talks. Jindrichuv Hradec.

Lestari, W.M., Sumabrata, J. (2018). The influencing factors on place attachment in the neighbourhood of Kampung Melayu. IOP Conference Series: Earth and Environmental Science 126. IOP Publishing.

Liputan 6 (2020), Banjir Kiriman Mulai Hampiri Jakarta, Air Kali Ciliwung di Kampung Pulo Meluap, 
$<$ https://www.liputan6.com/news/read/4146403/banjir-kiriman-mulai-

hampiri-jakarta-air-kali-ciliwung-di-kampung-pulo-meluap $>$ (Accessed on 21 June 2020)

Mandala, Z. (2013). Resilient Infrastructure: "Konsep dan Strategi Perencanaan Pembangunan Transportasi Berkelanjutan", Studi Kasus: Kota Curitiba, Brazil. Yogyakarta: Universitas Gadjah Mada.

Marana, P., Eden, C., Eriksson, H., Grimes, C., Hernantes, J., Howick, S., Labaka, L., Latinos, V., Lindner, R., Majchrzak, T. A., Pyrko, I., Radianti, J., Rankin, A., Sakurai, M., Sarriegi, J. M., \& Serrano, N. (2019). Towards a resilience management guideline - Cities as a starting point for societal resilience. Sustainable Cities and Society, 48(March), 101531.

Nilsson, A., Wester, M., Lazarevic, D., \& Brandt, N. (2018). Smart homes, home energy management systems and real-time feedback: Lessons for influencing household energy consumption from a Swedish field study. Energy \& Buildings 179 (2018) 15-25

Renald, A., Tjiptoherijanto, P., Suganda, E., \& Djakapermana, R. D. (2016). Toward Resilient and Sustainable City Adaptation Model for Flood Disaster Prone City: Case Study of Jakarta Capital Region. Procedia - Social and Behavioral Sciences, 227(November 2015), 334-340.

Sitinjak, E., Meidityawati, B., Ichwan, R., Onggosandojo, N., \& Aryani, P. (2018). Enhancing Urban Resilience through Technology and Social Media: Case Study of Urban Jakarta. Procedia Engineering, 212(2017), 222-229.

Tempo (2020), Respons Banjir, Jakarta Smart City Rancang Aplikasi Baru, $<$ https://metro.tempo.co/read/1296228/respons-banjir-jakarta-smart-cityrancang-aplikasi-baru $>$ (Accessed on 21 June 2020)

The Jakarta Post (2014), Jakarta Launches Smart City Program, $<$ https:/www.thejakartapost.com/news/2014/12/16/jakarta-launches-smartcity-program.html $>$ (Accessed on 1 June 2020)

United Nations (2018), 68\% of the world population projected to live in urban areas by 2050, says UN, $<$ https://www.un.org/development/desa/en/news/population/2018-revision-ofworld-urbanization-prospects.html $>$ (Accessed 25 June 2020)

World Bank (2016), Keeping Indonesia's Capital Safer from Floods, $<$ https:/www.worldbank.org/en/news/feature/2016/01/08/keeping-indonesiascapital-safer-from-floods $>$ (Accessed on 20 June 2020)

World Bank. (2015). Output: DKI JAKARTA INFORMAL SETTLEMENT $M A P P I N G \quad$ (P121467). World Bank. Retrieved from http://pubdocs.worldbank.org/en/408201444418421010/Output-DKIJAKARTA-INFORMAL-SETTLEMENT-MAPPING

Zhu, S., Li, D., \& Feng, H. (2019). Is an intelligent city resilient? Evidence from China. Sustainable Cities and Society, 50(May), 101636. 
Widiachristy, Rachmanto: THE EFFECTIVENESS OF JAKARTA SMART CITY APPLICATION IN ENHANCING COMMUNITY RESILIENCE IN FACING FLOOD RISK

This Page is Intentionally Left Blank 